\title{
An Assessment of Health Related Quality of Life of HIV Positive Patients in Warangal Region
}

\author{
Gurram Navya Sri*, Poka Navya, Valluri Nagalakshmi, Guduru Vasudha, Jupally Venkateshwar Rao, \\ Komaram Swethanjali, Valupadas Chandrasheker, Vadlamanu Usha Rani, Kankala Mallesham, Akula \\ Venkataramaniah
}

Department of Pharmacy Practice, Talla Padmavathi College of Pharmacy, Warangal, Telangana, INDIA.

\begin{abstract}
Many of the people are infected with the pandemic disease HIV either knowingly or unknowingly. Those people are in a misconception that their lives are end if the disease has occurred and many are with stigma and feeling depressed as per the studies done. Our study aimed to assess their Health-related quality of life (HROOL) and find the factors responsible for their reduced Quality of life (OOL) by taking the appropriate interventions. Our study was a prospective observational study, which was carried out in a government ART centre in Warangal region MGM for 6 months from April 2018 to September 2018. The outpatients were given with a structured questionnaire of WHOQOL-BREF and their quality was assessed. The questionnaire included physical, psychological, social and environmental domains. The QOL scores were assessed and there was a follow up of those patients in their next visit to the hospital after counselling them. 688 patients were included in pre counselling interaction and 668 patients were followed in post counselling session. There was a higher mean score for environmental domain (32.07) before counselling the patients and there was a higher psychological mean (65.56) score after counselling. There was a statistically significant difference between the domains and within the domains with a $P$-value of $<0.0001$. This study strongly suggests that there is a need for establishing the counselling centres in hospitals for the patients suffering with HIV. Finally, the role of a clinical pharmacist is a crucial step in the improvement of the patient's psychological behaviour.
\end{abstract}

Key words: HIV/AIDS, HRQOL, WHOQOL-BREF, Clinical Pharmacist intervention, Mahatma Gandhi Memorial Hospital (MGMH).

\section{INTRODUCTION}

\begin{abstract}
AIDS (acquired immunodeficiency syndrome) is caused by a virus called HIV (human immunodeficiency virus) I and II. The disease alters the immune system, making people much more vulnerable to infections and diseases. The susceptibility of the disease may get worsened if the symptoms progress. ${ }^{1}$
\end{abstract}

Presently, developing countries comprise majority of cases and Africa alone constitutes $50 \%$ of all positive cases globally. According to some estimate 1 in every 100 adults were with HIV. Half of all serologically positive cases are in women while children comprise $5 \%$ of all cases. According to the WHO data, the last decade has shown increased incidence of cases in Indian sub-continent.
However, giving exact figures of cases is pointless since the numbers are increasing by millions and all such data become outdated with every passing year. About 2.5 million new cases are getting added every year. In India, epicentres of the epidemics majority of the cases are through sexual transmission and next due to IV drug abusers. ${ }^{2}$

Right from the discovery of Human immunodeficiency virus (HIV) it has been the pandemic over all world with minimal life expectancy., ${ }^{3,4}$ But the discovery of Anti-retroviral drugs really improved the life expectancy of the people living with HIV. ${ }^{5}$ However HIV related stigma, psychological distress, depression were considered as the major barriers for preventing HIV
DOI: 10.5530/ijopp.12.1.5

Address for correspondence: Miss. Navya Sri Gurram, Pharm-D

Department of Pharmacy Practice, Intern in Samraksha Super Speciality Hospital, Warangal, Telangana, INDIA. Phone no: +919989745709 Email Id: navyasrigurram123@ gmail.com

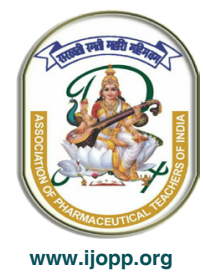


worldwide. ${ }^{6-9}$ However there is a great requirement for assessing the quality of life of those people living with HIV.

The need of the study was to assess and evaluate the health related quality of life of the people living with HIV. Warangal region. Even though patients receive therapy for disease that may only reduce their risk of transmitting the virus or developing HIV related illness it do not provide the psychological support which is a must in HIV patients to survive their lives happily. In order to achieve this there is a need for assessing their QOL. Many of the studies found that there was a reduced QOL in patients with $\mathrm{HIV} .{ }^{10}$ In our study the factors responsible for reduced QOL were found and what measures should be taken to improve the patients QOL was assessed by making appropriate interventions.

By improving the patients' health related quality of life by appropriate interventions the role of a clinical pharmacist gained much importance in the busy hospitals. The patient's insight and perceptions of their life was completely brought to a positive vision.

Quality of life is the term which conveys the complete meaning of well-being including the individual's happiness and satisfaction in their life. It is actually more broad and subjective. Health is the most important domain of complete Quality of life. There are various domains of Quality of life that comprises of jobs, housing, schools, neighborhood, culture, values, spirituality which may add to the complexity for its measurement.

\section{WHOQOL-BREF SCALE}

WHOQOL-BREF is having 26 items with four basic domains. WHOQOL-BREF domains are under the table given below

\section{1) Physical health}

Treatment dependence, fatigue, energy, movement, pain, comfort, sleep, daily activities, strength to work.

\section{2) Psychological well being}

Affection, positivity, negativity, good cognition, spirituality.

\section{3) Social relations}

Social contacts, family support, sexual activity.

\section{4) Environment}

Freedom, homely environment, safe and secure, refreshment with innovative activities, social responsibility.

\section{Each item uses a five-point Likert-type scale}

All the items were scored within the range of 1 to 5 . The scores of 3 negative items were reversed. The raw data was transformed to final scale of $0-100 .{ }^{11}$

\section{MATERIALS AND METHODS}

\section{Study Site}

The study was conducted in AR'T plus, Centre Department of Medicine. Mahatma Gandhi Memorial Hospital of Warangal region. It is an out-patient and in-patients based government hospital in Warangal. The patients from various places visit this hospital for treatment of various diseases and related complications.

\section{Study Design}

The present study is a cross sectional prospective Interventional study.

\section{Study Period}

The study was conducted for a period of six months from April 2018 to September 2018.

\section{Study Criteria}

\section{Inclusion Criteria}

- $\quad$ Patients of HIV positive and of either sex.

- Inpatients and out patients.

- $\quad$ Patients with co-morbidities.

- Patients who are willing to fill informed consent form.

- Patients who are pregnant.

\section{Exclusion Criteria}

- Patients who are having mental instability, hearing or cognitive impairment.

- Patients who don't will to participate in the study.

\section{Source of Data}

\section{All the Relevant and Necessary Data will be Collected from}

- Patient case notes

Indian Journal of Pharmacy Practice, Vol 12, Issue 1, Jan-Mar, 2019 
- By interviewing the patient and patient care takers.

- Laboratory data

All the collected data was documented in a suitably designed data collection form developed for the study.

\section{Ethics Committee Approval}

The protocol of the study including the introduction, objectives, data collection form and methodology was submitted for the approval of ethics committee members.

\section{Methodology}

- The study team visited the study sites every day on regular basis.

- $\quad$ Patients meeting the inclusion and exclusion criteria was selected for the study.

- The patient was explained in detail about the study and asked to provide the informed consent form.

- All the relevant patient data was collected from the patient and documented in a suitably designed data collection form.

- All collected data was analyzed using relevant statistical method.

\section{Designing of Data Collection Form}

A suitable data collection form was designed to collect, document and analyze the data. Informed consent section was also incorporated in the data collection form. Data collection form included the provision for collection related to demographic details of patient (Name, Age and Sex), employment status and education status and co morbidities.

\section{Scales Used}

QOL was evaluated using WHO QOL-BREF instrument ideally suited for busy clinics. WHO QOL-BREF has 26 items grouped under four domains.

\section{Physical health}

Treatment dependence, fatigue, energy, movement, pain, comfort, sleep, daily activities, strength to work.

\section{Psychological Well Being}

Affection, positivity, negativity, good cognition, spirituality.

Indian Journal of Pharmacy Practice, Vol 12, Issue 1, Jan-Mar, 2019

\section{Social relations}

Social contacts, family support, sexual activity.

\section{Environment}

Freedom, homely environment, safe and secure, refreshment with innovative activities, social responsibility.

\section{Statistical Methods}

Data was collected and analyzed through the software "Graph Pad Prism". The statistics used for analysis the data was "one- way Anova -Turkey multiple comparison test". P value less than 0.05 were considered as significant. SPSS was used for analysis of gender wise domains. There was a $P$ value of less than 0.05 and was statistically significant.

\section{RESULTS}

Total number of subjects who took part in the study was 688. Each patient was given a structured questionnaire of WHOQOL-BREF and their quality was assessed by the obtained scores. The same patient was followed for the next visit and same was done to find whether there is any improvement in their quality of life by the pharmacist counseling.

Almost 18 patients missed the second follow-up and 2 patients refused to participate in the study due to personal reasons.

Many of the patients with HIV are most depressed due to their unhealthy lifestyle and a negative impact of society Low Socio Economic Status towards them. This was analyzed by following the patients with utmost care and provided the psychological support by our counseling.

Table 1 shows among 354 females 254 (71.75\%) were married, $62(17.51 \%)$ were widowed, $24(6.77 \%)$ were divorced, $14(3.95 \%)$ were unmarried. Table 2 reveals that Out of 275 male patients $246(89.45 \%)$ were married, $21(7.63 \%)$ were unmarried and $8(2.90 \%)$ got divorced. Table 3 shows that among 668 patients 128 $(19.16 \%)$ patients were occasionally alcoholic, 19 (2.84\%) were chronic alcoholic, 41 (6.13\%) were smokers and $12(1.79 \%)$ patients were both smoker and alcoholic. Table 4 shows that co morbidities of all the patients were shown in the table given below. Of 668 patients majority of the patients co morbidities were nothing significant, $56(8.38 \%)$ patients had T.B, 19 (2.84\%) were with hypertension, $8(1.19 \%)$ were with type-2 DM, 5 $(0.74 \%)$ were with scabies, 6 were with renal calculi, thrombocytopenia and U.T.I and 2 patients were with 
Table 1: Marital status in female patients.

\begin{tabular}{ccc} 
MARITAL STATUS & $\begin{array}{c}\text { NO. OF } \\
\text { PATIENTS }\end{array}$ & PERCENTAGE (\%) \\
\hline MARRIED & 254 & 71.75 \\
WIDOWED & 62 & 17.51 \\
DIVORCED & 24 & 6.77 \\
UNMARRIED & 14 & 3.95 \\
TOTAL & 354 & 99.98 \\
\hline
\end{tabular}

Table 2: Marital status in male patients.

\begin{tabular}{ccc} 
MARITAL STATUS & $\begin{array}{c}\text { NO. OF } \\
\text { PATIENTS }\end{array}$ & PERCENTAGE (\%) \\
\hline MARRIED & 246 & 89.45 \\
UNMARRIED & 21 & 7.63 \\
DIVORCED & 8 & 2.90 \\
TOTAL & 275 & 99.98 \\
\hline
\end{tabular}

Table 3: Social history wise distribution of patients.

\begin{tabular}{ccc}
\hline SOCIAL HISTORY & $\begin{array}{c}\text { NO. OF } \\
\text { PATIENTS }\end{array}$ & PERCENTAGE (\%) \\
\hline NOTHING SIGNIFICANT & 468 & 70.05 \\
OCCASIONALLY & & 19.16 \\
ALCOHOLIC & 128 & \\
SMOKER & 41 & 6.13 \\
CHRONIC ALCOHOLIC & 19 & 2.84 \\
SMOKER AND & 12 & 1.79 \\
ALCOHOLIC & 12 & 99.97 \\
TOTAL & 668 & \\
\hline
\end{tabular}

\begin{tabular}{|ccc|}
\hline \multicolumn{2}{c|}{ Table 4: Co morbidities in HIV patient. } \\
$\begin{array}{c}\text { TYPE OF } \\
\text { COMORBIDITY }\end{array}$ & $\begin{array}{c}\text { NO. } \\
\text { OFPATIENTS }\end{array}$ & $\begin{array}{c}\text { PERCENTAGE } \\
(\%)\end{array}$ \\
\hline NOTHING SIGNIFICANT & 572 & 85.62 \\
TUBERCULOSIS & 56 & 8.38 \\
HYPERTENSION & 19 & 2.84 \\
TYPE-2 DM & 8 & 1.19 \\
SCABIES & 5 & 0.74 \\
RENAL CALCULI & 2 & 0.29 \\
THROMBOCYTOPENIA & 2 & 0.29 \\
UTI & 2 & 0.29 \\
PARALYSIS & 1 & 0.14 \\
HYPOTENSION & 1 & 0.14 \\
TOTAL & 668 & 99.92 \\
\hline
\end{tabular}

\section{Psychological domain unpaired t-test}

\begin{tabular}{cc}
\hline $\begin{array}{c}\text { Column A vs column B } \\
\text { Unpaired t-test } \\
p \text {-value }\end{array}$ & $<0.0001$ \\
Are means significantly different? & Yes \\
$(<0.05)$ & \\
One or two tailed p-value? & Two tailed \\
T,df & $\mathrm{T}=99, \mathrm{df}=1334$ \\
How big is the difference? & $22.7 \pm 0.1792 \mathrm{~N}=668$ \\
Mean \pm SEM of column A & $65.56 \pm 0.3939 \mathrm{~N}=668$ \\
Mean \pm SEM of column B & $-42.84 \pm 0.4328$ \\
Difference between means & -43.69 to -41.99 \\
$95 \%$ confidence interval & 0.8802 \\
R squared & \\
F test to compare variances & $4.833,667,667$ \\
F,DFn,Dfd & $<0.0001$ \\
$p$-value & Yes \\
\hline Are variances significantly different? &
\end{tabular}

Indian Journal of Pharmacy Practice, Vol 12, Issue 1, Jan-Mar, 2019 
Social domain unpaired t-test

\begin{tabular}{|c|c|}
\hline Column A vs column B & \\
\hline \multicolumn{2}{|l|}{ Unpaired t-test } \\
\hline$p$-value & $<0.0001$ \\
\hline $\begin{array}{l}\text { Are means significantly } \\
\text { different? }(<0.05)\end{array}$ & Yes \\
\hline One or two tailed p-value? & Two tailed \\
\hline T,df & $T=80.95, d f=1333$ \\
\hline \multicolumn{2}{|l|}{ How big is the difference? } \\
\hline Mean \pm SEM of column $\mathrm{A}$ & $16.88 \pm 0.3224 \mathrm{~N}=667$ \\
\hline Mean \pm SEM of column $B$ & $60.14 \pm 0.4261 \mathrm{~N}=668$ \\
\hline Difference between means & $-43.26 \pm 0.5344$ \\
\hline $95 \%$ confidence interval & -44.31 to -42.22 \\
\hline $\mathrm{R}$ squared & 0.831 \\
\hline \multicolumn{2}{|l|}{$\mathrm{F}$ test to compare variances } \\
\hline F,DFn,Dfd & $1.749,667,666$ \\
\hline$p$-value & $<0.0001$ \\
\hline $\begin{array}{c}\text { Are variances significantly } \\
\text { different? }\end{array}$ & Yes \\
\hline
\end{tabular}

\section{Environmental domain unpaired t-test}

\begin{tabular}{|c|c|}
\hline Column A vs Column B & $\mathrm{x}$ \\
\hline \multicolumn{2}{|l|}{ Unpaired t-test } \\
\hline$p$-value & $<0.0001$ \\
\hline $\begin{array}{l}\text { Are means significantly } \\
\text { different? }(<0.05)\end{array}$ & Yes \\
\hline One or two tailed p-value? & Two tailed \\
\hline $\mathrm{T}, \mathrm{df}$ & $\mathrm{T}=28.65, \mathrm{df}=1334$ \\
\hline \multicolumn{2}{|l|}{ How big is the difference? } \\
\hline Mean \pm SEM of column $A$ & $32.07 \pm 0.4636 \mathrm{~N}=668$ \\
\hline Mean \pm SEM of column $B$ & $47.42 \pm 0.2690 \mathrm{~N}=668$ \\
\hline Difference between means & $-15.35 \pm 0.5360$ \\
\hline $95 \%$ confidence interval & -16.40 to -14.30 \\
\hline $\mathrm{R}$ squared & 0.3809 \\
\hline \multicolumn{2}{|l|}{$\mathrm{F}$ test to compare variances } \\
\hline F,DFn,Dfd & $2.969,667,667$ \\
\hline$p$-value & $<0.0001$ \\
\hline $\begin{array}{c}\text { Are variances significantly } \\
\text { different? }\end{array}$ & Yes \\
\hline
\end{tabular}

Analysis of variance was used to compare all the domain scores of pre-counseling with post-counseling.

\section{One-way anova for pre-counselling domains}

\begin{tabular}{|c|c|c|c|c|}
\hline \multicolumn{5}{|l|}{ One-way analysis of variance } \\
\hline$p$-value & $<0.0001$ & & & \\
\hline Are means significantly different? $(p<0.05)$ & Yes & & & \\
\hline No. of groups & 4 & & & \\
\hline $\mathrm{F}$ & 487.5 & & & \\
\hline R squared & 0.3541 & & & \\
\hline \multicolumn{5}{|l|}{ Bartlett's test for equal variances } \\
\hline Bartlett's statistic(corrected) & 661 & & & \\
\hline$p$-value & $<0.0001$ & & & \\
\hline $\begin{array}{l}\text { Do the variances significantly differ? } \\
\qquad(p<0.005)\end{array}$ & Yes & & & \\
\hline ANOVA Table & SS & Df & MS & \\
\hline Treatment (between columns) & 99020 & 3 & 33010 & \\
\hline Residual (within columns) & 180600 & 2667 & 67.71 & \\
\hline Total & 270600 & 2670 & 33077.71 & \\
\hline Tukey;s Multiple comparison test & Mean difference & $q$ & Significant? $(<0.05)$ & $95 \% \mathrm{Cl}$ of diff \\
\hline D1 PC vs D2 PC & -5.246 & 16.48 & Yes & -6.404 to -4.087 \\
\hline D1 PC vs D3 PC & 0.593 & 1.862 & No & -0.5660 to 1.752 \\
\hline D1 PC vs D4 PC & -14.6 & 45.84 & Yes & -15.75 to -13.44 \\
\hline D2 PC vs D3 PC & 5.839 & 18.33 & Yes & 4.679 to 6.998 \\
\hline D2 PC vs D4 PC & -9.35 & 29.37 & Yes & -10.51 to -8.192 \\
\hline
\end{tabular}




\section{One-way anova for post counselling domains}

\begin{tabular}{|c|c|c|c|c|}
\hline \multicolumn{5}{|l|}{ One-way analysis of variance } \\
\hline$p$-value & $<0.0001$ & & & \\
\hline Are means significantly different? $(p<0.05)$ & Yes & & & \\
\hline No. of groups & 4 & & & \\
\hline $\mathrm{F}$ & 505.1 & & & \\
\hline $\mathrm{R}$ squared & 0.3622 & & & \\
\hline \multicolumn{5}{|l|}{ Bartlett's test for equal variances } \\
\hline Bartlett's statistic(corrected) & 146.3 & & & \\
\hline$p$-value & $<0.0001$ & & & \\
\hline Do the variances significantly differ? $(p<0.005)$ & Yes & & & \\
\hline ANOVA Table & SS & Df & MS & \\
\hline Treatment (between columns) & 136000 & 3 & 45340 & \\
\hline Residual (within columns) & 239500 & 2668 & 89.76 & \\
\hline Total & 375500 & 2671 & 45429.76 & \\
\hline Tukey;s Multiple comparison test & Mean difference & $q$ & Significant? $(<0.05)$ & $95 \% \mathrm{Cl}$ of diff \\
\hline D1 POC vs D2 POC & -14.2 & 38.73 & Yes & -15.53 to -12.86 \\
\hline D1 POC vs D3 POC & -8.78 & 23.95 & Yes & -10.11 to -7.446 \\
\hline D1 POC vs D4 POC & 3.942 & 10.75 & Yes & 2.608 to 5.276 \\
\hline D2 POC vs D3 POC & 5.418 & 14.78 & Yes & 4.084 to 6.752 \\
\hline D2 POC vs D4 POC & 18.14 & 49.48 & Yes & 16.81 to 19.47 \\
\hline D3 POC vs D4 POC & 12.72 & 34.7 & Yes & 11.39 to 14.06 \\
\hline
\end{tabular}

Analysis of variance was also performed for all the domains of females, males, pediatrics and trans genders separately and there was a significant difference between their means and standard deviations with a p-value of $<0.05$

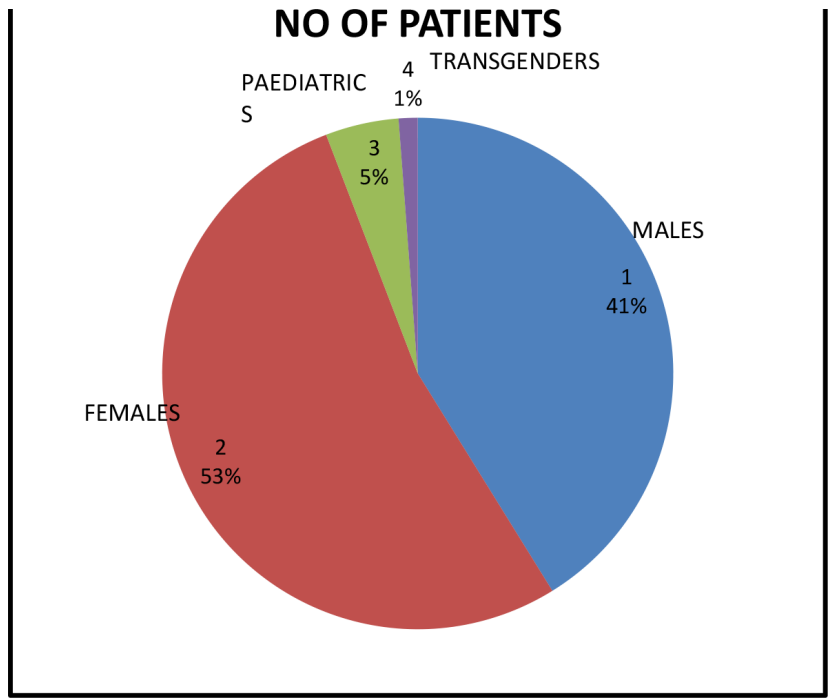

Figure 1: Gender wise distribution.

paralysis and hypotension.

However, Figure 1 shows that majority of the infected population were females in our study. Figure 2 shows

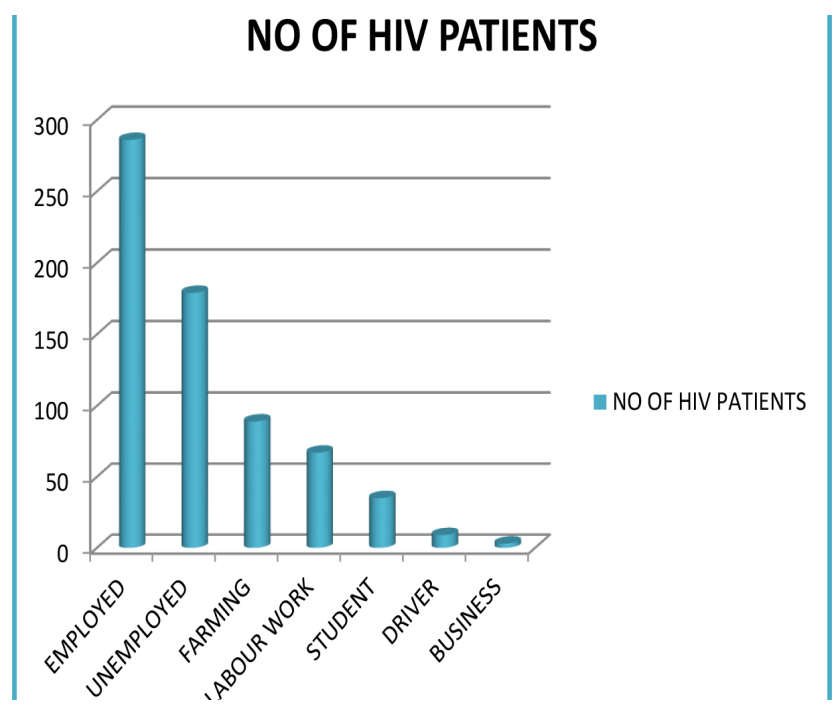

Figure 2: Employment status wise distribution.

that out of $668(99.95 \%)$ patients $286(42.81 \%)$ were employed, 179 (26.79\%) were unemployed, 89 (13.32\%) were farmers, $67(10.02 \%)$ were labour workers, 35 $(5.23 \%)$ were students, $9(1.34 \%)$ were drivers and 3 Indian Journal of Pharmacy Practice, Vol 12, Issue 1, Jan-Mar, 2019 


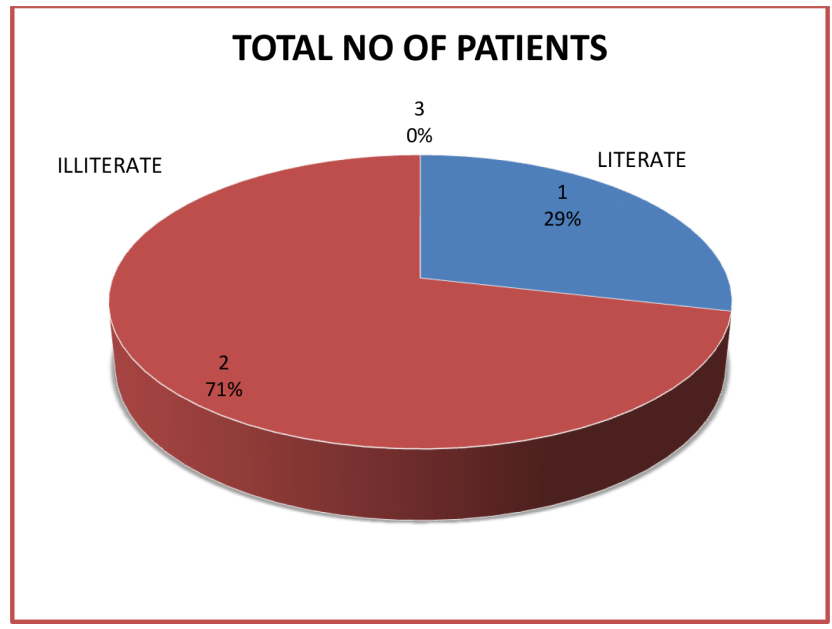

Figure 3: Educational status wise distribution.

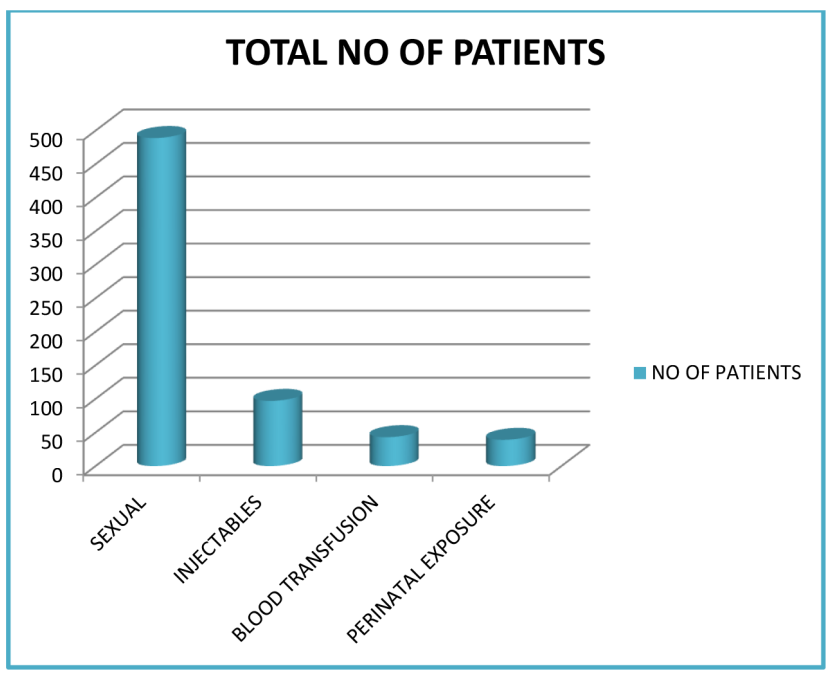

Figure 4: Mode of transmission wise distribution.

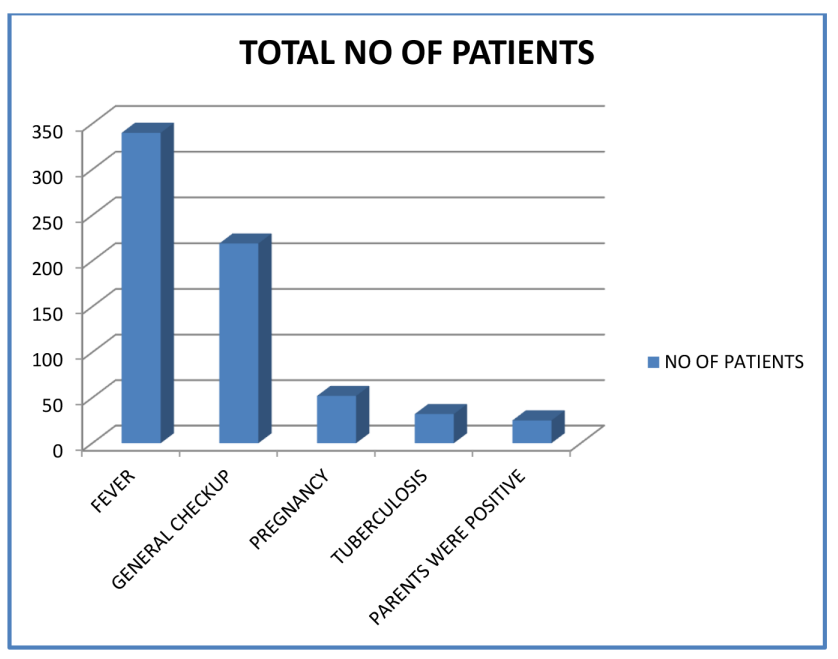

Figure 5: Distribution based on history of presenting illness.

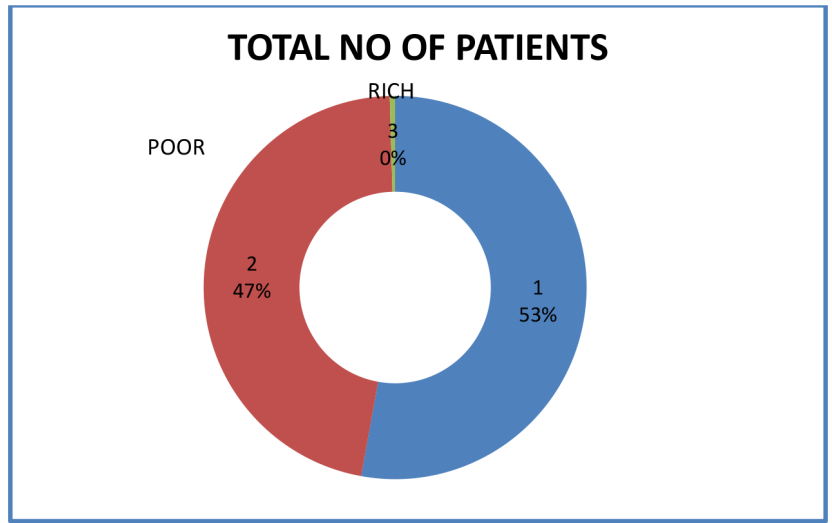

Figure 6: Economical status wise distribution.

\section{TOTAL NO OF PATIENTS}

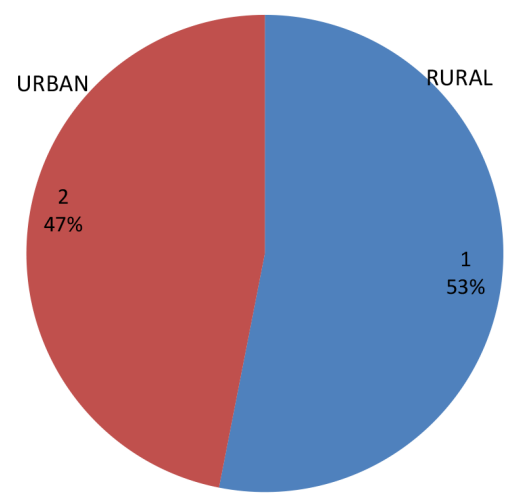

Figure 7: Region wise distribution.

$(0.44 \%)$ were business magnates. Figure 3 reveals that out of 668 patients $477(71.40 \%)$ were illiterates and 191 $(28.59 \%)$ were literates.

Figure 4 reveals that in a total of 668 patients the virus got transmitted majorly through sexual route that is 489 $(73.2 \%)$ patients, $97(14.52 \%)$ patients got transmitted through injectables, $43(6.43 \%)$ patients got transmitted through blood transmission and 39 (5.83\%) patients got transmitted through perinatal exposure.

Figure 5 shows in a total of 668 patients 340 (50.89\%) presented to hospitals with fever, $219(32.78 \%)$ presented through general checkup, $52(7.78 \%)$ patients presented when they were pregnant, $32(4.79 \%)$ patients presented through T.B and $25(3.74 \%)$ patients presented the illness right from their birth. Figure 6 reveals that in a total of 668 patients it was found that $353(52.84 \%)$ were middle class, $312(46.7 \%)$ were poor and $3(0.44 \%)$ were rich

Figure 7 shows that out of 668 patients 437 (65.41\%) were from rural area and $231(34.58 \%)$ were from urban 
area.

\section{Statistical Analysis}

1. Descriptive statistics were performed for all continuous variables by using percentage/frequency.

2. Inferential statistics were performed for the comparison of quality of life of patients before and after counseling.

3. T-test application helped us to compare the individual domain scores of pre-counseling with post-counseling.

4. There was a statistical difference between individual domains.

5. Analysis of variance was used to compare all the domain scores of pre-counseling with postcounseling.

6. Analysis of variance was also performed for all the domains of females, males, pediatrics and trans genders separately and there was a significant difference between their means and standard deviations with a $p$-value of 0.05 .

\section{DISCUSSION}

Our study is a follow-up study with almost 668 patients. It was found that there was a significant improvement in the patient's physical, psychological, social and environmental behavior before and after counseling. Our study found that in pre-counseling interaction with patients the mean score $(0-100)$ of domains was highest for the environmental domain (32.07), followed by psychological domain (22.72), then physical (17.47) and lowest for social (16.88).

In post-counseling interaction with patients the mean score $(0-100)$ of domains was highest for psychological domain (65.56), followed by social domain (60.14), then physical domain (51.36) and lowest for environmental (47.42) when compared with other study done by B. Nirmal et al. ${ }^{11}$

Gender wise analysis was also done and the mean score for men was higher to females mean score. The precounseling interaction with females, males, pediatrics and trans genders was found to be highest in environmental domain and the post-counseling interaction was to be highest in psychological domain when compared with other work (results) of Huanguang Jia et al. ${ }^{13}$
Our study consists of majority of female patients (52.995), Majority were illiterates (71.4\%). In our study education was also considered as a barrier in their quality of life improvement. Many of them are from rural area $(65.41 \%)$.

As majority of patients were illiterate there is a need for making them aware of their disease condition. Hence there is a role of clinical pharmacist in counseling the patients. Our study improved the quality of life of people living with HIV and this was considered as the major step that has to be taken by all the health care professionals as per the previous study done by Doris Mutabazi-Mwesigire et al. ${ }^{12}$

\section{CONCLUSION}

This study clearly outputs the health related quality of life of HIV patients has as an association with the four domains that were under the WHOQOL-BREF scale. Our study used WHOQOL-BREF scale to assess the health related quality of life of people living with HIV. The pre-counseling session showed increased scores in environmental domain and post-counseling interaction showed increased scores in psychological domain which is a must in those patients as many of them are with depression.

Moreover the QOL of patients could be enhanced with time by providing counseling sessions and by encouraging their family members to support them and create employment opportunities for PLWHIV.

Our study also found that education will also be a barrier for their reduced QOL. Therefore the education of patients was done by appropriate patient information leaflets.

Finally the role of a clinical pharmacist is a crucial step in the improvement of the patient's psychological behavior and to reduce their depression.

\section{ACKNOWLEDGEMENT}

The authors wish to thank the superintendent, Mahatma Gandhi Memorial Hospital of Warangal District for permitting us to carry out the study. We also thank our guides Dr. J. Venkateshwar Rao, Varun Talla, Dr. K. Sathyanarayan Patnaik, Dr. V. Srinivas, H.N. Vishwas, Dr. K. Swethanjali, for their endless support in carrying out the study.

We are most grateful to the nodal officer of MGM Indian Journal of Pharmacy Practice, Vol 12, Issue 1, Jan-Mar, 2019 
Hospial, Senior medical officer of ART centre, MGM in giving us support in carrying out the study without any obstacles.

\section{CONFLICT OF INTEREST}

The authors declare no conflicts of interest

\section{ABBREVIATIONS}

HIV: Human immunodeficiency virus; AIDS: Acquired immunodeficiency syndrome; W.H.O: World Health Organisation; ART: Antiretroviral Therapy; QOL: Quality of Life; HRQOL: Health Related Quality of Life; PLWHIV: People Living With HIV.

\section{SUMMARY}

Assessing HRQOL of HIV positive patients revealed greater need of psychological assistance to be provided by the counselling sessions. Therefore the need of such activities which improve the psychological behaviour of the patients are quite prominent.

\section{REFERENCES}

1. https://www.medicalnewstoday.com/articles/17131.php.

2. Harshmohan. Textbook of pathology sixth edition, Jaypee Brothers Medical Publishers (P) Ltd. 2010;67-73.

3. Walker N, Grassly NC, Garnett GP, Stanecki KA, Ghys PD. Estimating the global burden of HIVIAIDS: what do we really know about the HIV pandemic? Lancet. 2004;363(9427):2180-5.

4. Beck E, Miners A, Tolley K. The cost of HIV treatment and care. A global review. Pharmacoeconomics. 2001;19(1):13-39.

5. Fauci AS. The AIDS Epidemic. Considerations for the $21^{\text {st }}$ Century. $\mathrm{N}$ Engl $\mathrm{J}$ Med. 1999;341(14):1046-50.

6. Foreman M, Lyra P, Breinbauer C. Understanding and Responding to HIV/ AIDS-Related Stigma and Discrimination in the Health Sector. Washington, DC: Pan American Health Organization. 2003.

7. Mahajan AP, Sayles JN, Patel VA, Remien RH, et al. Stigma in the HIVIAIDS epidemic: a review of the literature and recommendations for the way forward. AIDS. 2008;22(suppl 2):S67-79.

8. Rahmati-Najarkolaei F, Niknami S, Aminshokravi F, et al. Experiences of stigma in healthcare settings among adults living with HIV in the Islamic Republic of Iran. J Int AIDS Soc. 2010;13(1):27.

9. Piot P. AIDS: from crisis management to sustained strategic response. Lancet. 2006;368(9534):526-30.

10. Kebede A, Teferi G, Ephrem E, Gebre-Mariam T. Quality of life of people living with HIVIAIDS and on highly active antiretroviral therapy in Ethiopia. African Journal of AIDS Research. 2010;9(1):31-40.

11. Nirmal B, Divya KR, Dorairaj VS, Venkateswaran K. QOL in HIVIAIDS patients: A cross sectional study in south India. Indian J Sex Transm Dis. 2008;29(1):15-6.

12. Mutabazi-Mwesigire D, Janet S, Faith M, Achilles K. Perceptions of QOL among Ugandan patients living with HIV: a qualitative study. 2014;14(1):343.

13. Huanguang J, Constance RU, Zheng Y, Samuel W, John CG, Kimberly F, et al. A further investigation of health-related quality of life over time among men with HIV infection in the HAART era. Qual Life Res. 2007;16(6):961-8. 